Simbiosis Mutualisme Perpustakaan dengan Media Cetak sebagai Upaya Membudayakan Membaca dan Menulis bagi Masyrakat Muhammad Rohmadi

- Faktor Pengembangan dan Isu dalam Masalah Karier Pustakawan Masriyatun

Menguak Informasi via Alexa.com sebagai Evaluasi Menuju Optimalisasi

- Keberaksesan terhadap Perpustakaan dan Institusinya Wiji Suwarno

Profesionalisme Pustakawan dalam Layanan Informasi SriAnawati

Public Space dan Private Space: Posisi Strategis Perpustakaan dalam Mendukung

Pembelajaran Kolaboratif Purwani Istiana

Mewujudkan World-class Professionalism of Librarians di Era Library Mobile

Yuni Nurjanah

- Tantangan dan Kesiapan Pustakawan di Era Digital Dian Hapsari

Formulasi Strategi Membangun Eksistensi Perpustakaan Perguruan Tinggi

(Studi UPT Perpustakaan UNS Tahun 2015) RiahWiratningsih

Optimalisasi Perpustakaan Desa dalam Rangka Meningkatkan Pendidikan Masyarakat Bambang Hemanto

Optimalisasi Layanan Perpustakaan Perguruan Tinggi melalui Pemanfaatan Social

- Media Networking sebagai Media Komunikasi antara Perpustakaan dan Pemustaka Haryanto

Rekonstruksi Budaya Hukum Masyarakat dalam Pemulihan Pascakonflik Etnis Madura dan Melayu di Kabupaten Sambas 


\section{Jurnal \\ Pustaka Ilmiah \\ Jurnal Ilmiah UPT Perpustakaan UNS}

Jurnal Pustaka Ilmiah (JPI) sebagai media kreasi para pustakawan, guru, dosen, dan praktisi dalam pengembangan profesi secara berkelanjutan. Berbagai ide dan gagasan kreatif menjadi bahan kajian yang diimplementasikan dalam berbagai model pengembangan bahan pustaka, baik cetak maupun online. Kreativitas menjadi akar pengembangan ilmu pengetahuan sepanjang hayat dengan berbagai model pengembangan budaya literasi di perpustakaan. Keindahan dan kecermatan dalam sebuah tulisan ilmiah dan nonilmiah akan dapat direalisasikan secara nyata oleh sumber daya manusia untuk menghasilkan SDM yang unggul dan kreatif dengan membaca dan menulis untuk menyinari dunia. Budaya literasi menjadi upaya untuk pengembangan dan pemberdayaan perpustakaan sebagai pusat sumber belajar untuk mendukung tri dharma perguruan tinggi.

\section{SUSUNAN REDAKSI JURNAL PUSTAKA ILMIAH UPT PERPUSTAKAAN UNS}

Penanggung Jawab

Ketua Redaksi

Wakil Redaksi

Sekretaris

Penyunting Ahli
: Dr. Muhammad Rohmadi, M.Hum.

: Dra. Tri Hardiningtyas, M.Si.

: Haryanto, M.IP.

: Bambang Hermanto, S.Pd., M.IP., Henny Perwitosari, A.Md.

: 1. Dr. Muhammad Rohmadi, M.Hum. (Universitas Sebelas Maret);

2. Drs. Widodo, M.Soc.Sc. (Universitas Sebelas Maret);

3. Drs. Harmawan, M.Lib. (Universitas Sebelas Maret).

: Daryono, S.Sos., M.IP.; RiahWiratningsih, S.S., M.Si., Dinar Puspita Dewi, S.Sos., M.IP.; Sri Utari, S.E.

: Nurul H., A. Md.; Novi Tri Astuti, A.Md.

: Aji Hartono, A. Md.; Agus Sriyono, A.Md.; Aris Suprihadi, S.IP.

\section{DITERBITKAN OLEH UPT PERPUSTAKAAN UNS}

REDAKSI JURNAL PUSTAKA ILMIAH

Alamat: Jl. Ir. Sutami 36A Kentingan, Surakarta 57126

Telp./Fax.: (0271) 654311; email: jurnal.pustaka.ilmiah@gmail.com 


\section{PENGANTAR REDAKSI}

Salam pustaka. Dengan rasa syukur kepada allah swt. Segenap redaksi Jurnal Pustaka Ilmiah (JPI) mengucapkan banyak terima kasih kepada para penulis yang telah berkontribusi untuk penerbitan perdana JPI. Dengan terbitnya JPI ini berarti UPT Perpustakaan UNS telah memiliki media penulisan bagai para pustakawan, dosen, tenaga kependidikan, guru, dan praktisi untuk menuangkan ide dan gagasan kreatifnya secara tertulis.

Dalam penerbitan JPI perdana ini disajikan sepuluh tulisan antara lain: (1) Faktor Pengembangan dan Isu Dalam Masalah Karier Pustakawan (Masriyatun), (2) Menguak Informasi via Alexa.com sebagai Evaluasi Menuju Optimalisasi Keberaksesan terhadap Perpustakaan dan Institusinya (Wiji Suwarno), (3) Profesionalisme Pustakawan dalam Layanan Informasi (Sri Anawati), (4) Public Space dan Private Space: Posisi Strategis Perpustakaan dalam Mendukung Pembelajaran Kolaboratif (Purwani Istiana), (5) Mewujudkan World-class Professionalism of Librarians di Era Library Mobile (Yuni Nurjanah), (6) Tantangan dan Kesiapan Pustakawan di Era Digital (Dian Hapsari), (7) Formulasi Strategi Membangun Eksistensi Perpustakaan Perguruan Tinggi (Studi UPT Perpustakaan UNS Tahun 2015) (Riah Wiratningsih), (8) Optimalisasi Perpustakaan Desa dalam Rangka Meningkatkan Pendidikan Masyarakat (Bambang Hemanto), (9) Optimalisasi Layanan Perpustakaan Perguruan Tinggi melalui Pemanfaatan Social Media Networking sebagai Media Komunikasi antara Perpustakaan dan Pemustaka (Haryanto).

Akhirnya, redaksi JPI mengucapkan banyak terima kasih kepada Kepala UPT Perpustakaan UNS yang telah memberikan dukungan dan memfasilitasi untuk penerbitan JPI. Selain itu, ucapan terima kasih juga disampaikan kepada para penulis, tim redaksi, dan Yuma Pressindo, yang telah mempersiapkan dari awal sampai terbitnya JPI.

Desember 2015

Ketua Redaksi, 


\section{SAMBUTAN}

Dr. Muhammad Rohmadi, M.Hum.

Kepala UPT Perpustakaan UNS

\section{“Jadikalah tulisanmu sebagai cermin kehidupanmu di masa sekarang dan masa depan"}

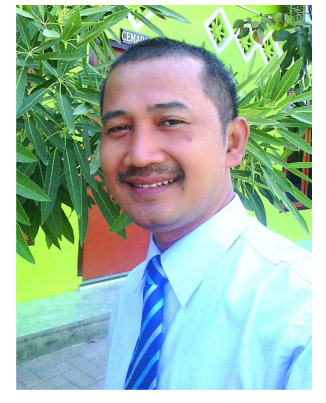

Selamat dan sukses atas diterbitkannya Jurnal Pustaka Ilmiah (selanjutnya disingkat JPI). Sambutan ini diberikan dalam rangka penerbitan perdana JPI. Jurnal ini sebagai media kreativitas dan pengembangan softskill para pustakawan, guru, dosen, dan praktisi untuk menuangkan ide dan gagasan dalam berbagai konteks kehidupan. Berbagai isu terkait dengan pengembangan perpustakan, pusat sumber belajar, pendidikan, dan budaya literasi akan menjadi topik-topik yang disajikan dalama jurnal ilmiah ini.

Diterbitkannya JPI sebagai bukti kepedulian UPT perpustakaan Ilmiah dalam rangka turut berpartisipasi untuk mengembangkan dan membudayakan literasi untuk para pustakawan dan civitas akademika di UNS dan luar UNS. Berbagai model pengembangan softskill menjadi alaternatif untuk membekali dan memperkuat jaringan kerja sama penulisan antarkelembagaan. Dengan demikian, kerja sama antarpustakawan dan pemustaka dapat diwujudkan dengan berbagai model dalam bidang literasi.

Penerbitan JPI sebagai upaya untuk memotivasi semua pustakawan menulis, baik ilmiah maupun nonilmiah. Para pustakawan harus menjadi pionir dalam bidang penulisan. Hal ini sebagai bentuk kepedulian dan keteladaan para pustakawan yang memproses, menyajikan, dan menikmati bahanbahan pustaka cetak dan noncetak di perpustakaan. Ketersedian bahan pustaka akan menjadi bahan paling nyata untuk dikembangkan dalam berbagai model perwujudan teknik peniulisan. Hal terpenting yang harus dimiliki oleh para pustakawan adalah semangat untuk berbagai pengetahuan melalui tulisan.

Kepedulian setiap sumber daya manusia kepada kelembagaan dapat dituangkan dalam berbagai model pengabdian, salah satunya adalah melalui tulisan. Berbagai ide dan gagasan dapat direalisasikan dengan berbagai model bentuk artikel jurnal, buku, modul, monograf, dan lain sebagainya. Para civitas akademika, guru, praktisi harus memiliki keterampilan menulis sebagai bentuk perwujudan pengembangan diri secara berkelanjutan. Berbagai tulisan dan referensi sudah disajikan tetapi masih sangat minim untuk diimplementasikan dalam kehidupan. Banyak orang pandai dalam berbicara tetapi masih sedikit yang menuangkan ide dan gagasannya dalam bentuk tulisan.

Akhirnya, keluarga besarUPT Perpustakaan UNS mengucapkan banyak terima kasih kepada Rektor, Wakil Rektor, pengelola JPI, penulis, dan semua pihak yang telah mendukung penerbitan perdana JPI. Semoga dengan diterbitkannya JPI ini dapat menjadi media untuk menulis para pustakawan, dosen, guru, dan praktisi dalam bidang iptek dan seni. Ucapan terima kasih juga diucapkan kepada percetakan Yuma Pressindo yang telah membantu mempersiapkan dari awal sampai terbitnya JPI ini. Akhirnya, semoga JPI dapat memberikan nilai kemaslahatan untuk umat.

“Berdiri kemudian berbaring sangatlah cepat tetapi tatkala sudah dituliskan akan menjadi kenangan yang taidak terlupakan sepanjang hayat”

Surakarta, Desember 2015 


\section{DAFTAR ISI \\ JURNAL PUSTAKA ILMIAH EDISI 1 VOLUME 1 TAHUN 2015}

Simbiosis Mutualisme Perpustakaan dengan Media Cetak sebagai Upaya Membudayakan Membaca dan Menulis bagi Masyrakat

Muhammad Rohmadi

Faktor Pengembangan dan Isu dalam Masalah Karier Pustakawan.

Masriyatun

Menguak Informasi via Alexa.com sebagai Evaluasi Menuju Optimalisasi Keberaksesan terhadap Perpustakaan dan Institusinya

Wiji Suwarno

Profesionalisme Pustakawan dalam Layanan Informasi

Sri Anawati

Public Space dan Private Space: Posisi Strategis Perpustakaan dalam Mendukung Pembelajaran Kolaboratif

Purwani Istiana

Mewujudkan World-class Professionalism of Librarians di Era Library Mobile

Yuni Nurjanah

Tantangan dan Kesiapan Pustakawan di Era Digital

Dian Hapsari

Formulasi Strategi Membangun Eksistensi Perpustakaan Perguruan Tinggi (Studi UPT Perpustakaan UNS Tahun 2015)

Riah Wiratningsih

Optimalisasi Perpustakaan Desa dalam Rangka Meningkatkan Pendidikan Masyarakat Bambang Hemanto

Optimalisasi Layanan Perpustakaan Perguruan Tinggi melalui Pemanfaatan Social Media Networking sebagai Media Komunikasi antara Perpustakaan dan Pemustaka Haryanto 


\title{
FORMULASI STRATEGI MEMBANGUN EKSISTENSI PERPUSTAKAAN PERGURUAN TINGGI (STUDI KASUS DI UPT PERPUSTAKAAN UNS)
}

\author{
Riah Wiratningsih \\ riahwiratningsih@yahoo.com / 087836698410
}

\begin{abstract}
"Library is the heart of the university" if science is blood in the body and the body is a system of a university, then for the university, library is the heart that bearing sciences and devotes to the students through the lecturer as the veins. From the statement above, the existence of a library as a resource center has a crucial function in academic activities. The purpose of this study was to find formulation strategies to establish the existence library of the university (UNS) using field survey method, description of existing phenomena, and literature study, the writer "captures" existence of the academic library in Sebelas Maret University through SWOT analysis. The results of this study were 1) SO Strategy: building a new differentiation service "Javanese Corner", adding the diversity of digilib content; 2) ST Strategy: SAT as media digital information search, building library as a learning center in creating academic atmosphere; 3) WO Strategy: accommodate the needs of the collections that have been segmented, proposing programmer for the development of library, share collections through "kartu sakti" FKP2TN; 4) WT Strategy: workshop on information literacy to all UNS librarians, bring up professional librarians in their roles through collaboration with lecturers in the utilization of library technology to support education and research. Hopefully, the results of this simple article can be implemented (followup) as part of the library management in the future so the existence of the library through the librarian's actions can be perceived maximally.
\end{abstract}

Keywords: library, learning center, existence, SWOT

\begin{abstract}
ABSTRAK
"Library is the heart of the university" andai ilmu adalah darah dalam tubuh dan tubuh merupakan sistem dari sebuah perguruan tinggi, maka perpustakaan bagi perguruan tinggi tersebut adalah jantung yang melahirkan ilmu yang ditujukan kepada mahasiswa melalui dosen sebagai pembuluh darahnya. Dari pernyataan di atas, eksistensi sebuah perpustakaan sebagai resource center mempunyai fungsi sangat krusial dalam kegiatan akademik di perguruan tinggi. Tujuan dari penelitian ini adalah untuk menemukan formulasi strategi membangun eksistensi perpustakaan perguruan tinggi (UNS), melalui metode survei lapangan, deskripsi fenomena yang ada, dan studi pustaka, kemudian diuraikan secara deskriptif kualitatif, penulis melakukan "capture" gambaran perpustakaan perguruan tinggi yaitu UPT Perpustakaan UNS melalui analisis SWOT. Adapun hasil dari penelitian ini adalah (1) Strategi SO: membangun differensiasi layanan baru "Javanese Corner", menambah ragam content digilib; 2) Strategi ST: layanan SAT sebagai media penelusuran informasi digital, lokasi perpustakaan yang strategis sebagai learning center dalam menciptakan
\end{abstract}


academic atmosphere; 3) Strategi WO: mengakomodasi kebutuhan informasi berdasar market share yang sudah tersegmetasi, pengajuan programmer untuk pengembangan SIM perpustakaan, share collection melalui kartu sakti FKP2TN. (4) Strategi WT: workshop literasi informasi untuk semua pustakawan UNS, memunculkan pustakawan profesional dalam perannya melalui kolaborasi dengan tenaga pendidik (dosen) dalam pemanfaatan teknologi perpustakaan untuk mendukung pendidikan dan riset. Diharapkan, hasil tulisan sederhana ini dapat diimplementasikan (follow-up) sebagai bagian dari tata kelola perpustakaan ke depan sehingga eksistensi perpustakaan melalui pustakawan dapat dilihat dan dirasakan oleh pengguna perpustakaan secara maksimal.

Kata kunci: perpustakaan, learning center, eksistensi, SWOT

\section{PENDAHULUAN}

Era informasi yang ditandai dengan perkembangan teknologi informasi dan komunikasi, menuntut setiap organisasi untuk bergerak dengan cepat dalam menghadapi perubahan. Perkembangan pendidikan dengan berbagai seperangkat teknologi pembelajaran menjadi tantangan untuk dihadapi. Fenomena ini menuntut dunia pendidikan, salah satunya adalah Universitas Sebelas Maret yang memiliki visi menjadi pusat pengembangan ilmu, teknologi, dan seni yang unggul di tingkat internasional dengan berlandaskan pada nilai-nilai luhur budaya nasional, harus bergerak cepat. Dalam merespons upaya menuju visi universitas, tidak terlepas dari peran perpustakaan sebagai lembaga pengelola informasi, yang memiliki visi UPT Perpustakaan UNS menjadi pusat layanan informasi yang unggul di tingkat internasional. Perpustakaan sebagai core sumber pengetahuan dalam menunjang proses belajar mengajar, penelitian, dan pengabdian kepada masyarakat harus "seirama" dalam bergerak menuju visi universitas. Pengetahuan adalah sebuah kekuatan di era yang penuh kompetisi saat ini. Pakar pemasaran Indonesia Gymnastiar \& Kartajaya (2004: 18) dalam suatu kredo yang terkenal dengan The 10 Credos of Compassionate Marketing di mana kredo kedua adalah "Be sensitive to change and be ready to transform”, menyebutkan:
"Dunia tidak akan selamanya seperti ini. Lanskap bisnis akan terus berubah. Kompetisi yang semakin sengit tidak mungkin dihindari lagi. Globalisasi dan teknologi akan membuat pelanggan semakin pintar. Kalau kita tidak sensitif dan tidak cepat-cepat mengubah diri, maka kita akan habis."

Pustakawan sebagai pengelola perpustakaan dituntut untuk adaptif dalam menyikapi perubahan kultur masyarakatnya. Keberadaan perpustakaan merupakan representasi dari kualitas masyarakatnya. Peran perpustakaan sebagai core pengetahuan memiliki tanggung jawab dalam memberikan akses secara mudah dan tepat dengan memanfaatkan teknologi informasi. Kualitas sebuah perguruan tinggi pun bisa dilihat melalui representasi perpustakaan sebagai jantung perguruan tinggi. "Library is the heart of the university" andai ilmu adalah darah dalam tubuh dan tubuh merupakan sistem dari sebuah perguruan tinggi, maka perpustakaan bagi perguruan tinggi tersebut adalah jantung yang melahirkan ilmu yang ditujukan kepada anak didik (mahasiswa) melalui dosen sebagai pembuluh darahnya. "Food for brain" tersedia di perpustakaan, "health food" yang disajikan di perpustakaan akan menghasikan kualitas sumber daya manusia.

UPT Perpustakaan UNS yang berdiri pada 14 Agustus 1980, dalam perjalanannya telah 
mengalami beberapa kemajuan. Satu langkah awalnya UPT Perpustakaan telah meraih sertifikasi ISO 9001:2008 pada bulan November 2010. Total quality management sebagai indikator customer need yang berorientasi pada kepuasan pengguna, memerlukan dukungan pemanfaatan teknologi informasi yang selalu baru. Namun, hal ini dilematis untuk keberadaan perpustakaan, di satu sisi dituntut untuk memberikan layanan prima, di sisi lain lambatnya akselerasi dalam layanan berbasis teknologi karena keterbatasan sarana di bidang teknologi, sumber daya manusia yang kurang optimal (sudah bearada di zona nyaman), dan bargaining position yang masih rendah. Perlu dilakukan analisis secara internal dan eksternal untuk beradaptasi terhadap perubahan, di mana setiap perubahan akan melibatkan banyak pihak dalam tingkat manajemen (tata kelola) sebuah perguruan tinggi. Untuk itu, diperlukan suatu tata kelola, formulasi strategi apa saja yang perlu diimplementasikan oleh UPT Perpustakan UNS dalam membangun eksistensi di perguruan tinggi.

Penelitian ini menggunakan metode survei lapangan (field survey method), data hasil pengamatan empiris, studi pustaka diuraikan secara deskriptif kualitatif (qualitative descriptive). Penulis melakukan observasi partisipasi sedang (moderet participation) di mana penulis dalam mengumpulkan data melalui pengamatan dan keterlibatan dalam beberapa kegiatan yang terjadi di UPT Perpustakaan UNS menggunakan pendekatan analisis SWOT. Berdasarkan analisis internal, akan dirumuskan variabel kekuatan dan kelemahan. Melalui analisis eksternal, akan dirumuskan variabel peluang dan ancaman. Dengan pemahaman mengenai faktor-faktor internal dan eksternal, UPT Perpustakaan UNS diharapkan akan berada pada posisi yang ideal untuk menanggapi perubahan-perubahan lingkungan. Tentu saja perlu didukung oleh pihak pengambil kebijakan di tingkat universitas. Setiap perubahan eksternal diharapkan akan segera direspons sehingga perpustakaan yang fleksibel dapat mengambil langkah-langkah tepat dan akhirnya bargaining position/eksistensi perpustakaan akan dimunculkan dalam setiap kegiatan akademik kampus.

Adapun batasan tulisan ini hanya memberikan hasil pada tataran formulasi strategi berdasarkan analisis situasi perpustakaan tahun 2015. Hasil dari tulisan sederhana ini diharapkan dapat diimplementasikan (followup) sebagai bagian dari tata kelola perpustakaan ke depansehingga eksistensi perpustakaan melalui pustakawan dapat dilihat dan dirasakan oleh pengguna perpustakaan secara maksimal.

\section{PEMBAHASAN}

\section{Manajemen Strategis}

Manajemen strategis membantu organisasi mengidentifikasi apa yang akan dicapai. Dalam wikipedia, disebutkan:

"Strategic management involves the formulation and implementation of the major goals and initiatives taken by a company's top management on behalf of owners, based on consideration of resources and an assessment of the internal and external environments in which the organization competes."

Untuk mencapai tujuan organisasi, diperlukan formulasi strategi melalui analisis terhadap lingkungan internal dan eksternal organisasi. Rothaermel (2013: 5) menyatakan "strategic management an integrative management field that combines analysis, formulation, and implementation in the quest for competitive advantage". Manajemen strategis adalah suatu proses melalui tahapan yang saling berkaitan dan saling mempengaruhi. Saat ini kompetisi semakin kuat, perlu upaya memiliki keunggulan kompetitif. Kompetitor perpustakaan adalah lembaga penyedia informasi yang telah mengemas informasinya dengan pemanfaatan akses internet. Digital 
library adalah jawabannya dan kemasan informasi yang user friendly, informatif, unik adalah upaya dalam menciptakan keunggulan kompetitif. Perpustakaan menyediakan koleksi/ menciptakan layanan yang berbeda di antara penyedia layanan informasi yang lain untuk menciptakan unique position. Keunggulan kompetitif ini harus dapat dimanfaatkan secara optimal. Untuk itu, perlu perencanaan strategis. Bryson (dalam Mapulanga 2012: 72) menyatakan bahwa:

"strategic planning has enabled libraries as organisations to: think strategically; clarify future directions; make decisions in light of future consequences; develop a coherent and defensible basis for decision making; exercise maximum discretion in the areas under control; improve performance; solve major organisational problems; deal effectively with rapidly changing circumstances; and build teamwork and expertise."

\section{Analisis SWOT}

Perpustakaan harus melibatkan diri dalam perencanaan strategis karena perpustakaan adalah growing organism yang harus adaptif dengan adanya perubahan. Hal ini penting untuk menunjukkan kontribusi perpustakaan terhadap tujuan lembaga induknya. Analisis SWOT (strengths, weaknesses, opportunities, dan threats) adalah metode perencanaan strategis yang digunakan untuk mengevaluasi kekuatan, kelemahan, peluang, dan ancaman dalam suatu organisasi. Proses ini mengidentifikasi faktor internal dan eksternal UPT Perpustakaan UNS, kemudian menerapkannya dalam gambar matriks SWOT. Identifikasi SWOT merupakan hal penting untuk dapat menginformasikan langkah-langkah selanjutnya dalam perencanaan sebuah organisasi, baik perencanaan jangka pendek maupun jangka panjang. Drucker (dalam Mapulanga, 2012: 71 - 72) menyatakan bahwa:

"Management has no choice but to anticipate the future, to attempt to mould it, and to balance short range and long range goals. The future will not just happen if one wishes hard enough. It requires decisions-now. It imposes risknow. It requires action now. It demands allocation of resources, and above all, of human resources-now. It requires worknow."

Sedangkan menurut Team MFE (2013: 7) sebagai berikut.

"The SWOT analysis is a popular and versatile tool, but it involves a lot of subjective decision making at each stage. It should always be used as a guide rather than as a prescription and it is an iterative process. There is no such thing as a definitive SWOT for any particular organization because the strengths, weaknesses, opportunities, and threats depend to a large extent on the business objective under consideration."

Perlu ditekankan bahwa penggunaan teknik analisis SWOT melalui proses pengidentifikasian tujuan dan pengelompokan faktor-faktor SWOT adalah sama pentingnya karena antarfaktor saling berkaitan. Di bawah ini adalah analisis SWOT UPT Perpustakaan UNS tahun 2015. 
Tabel 1. Matriks SWOT UPT Perpustakaan UNS Surakarta

\begin{tabular}{|c|c|c|c|c|c|}
\hline & & & Strenght (S) & & Weakness $(\mathbf{W})$ \\
\hline & Faktor Internal & 1 & $\begin{array}{l}\text { Layanan SAT (Self Access } \\
\text { Terminal) } \\
\text { Layanan digilib.uns.ac.id } \\
\text { Koleksi Jawa } \\
\text { Letak UPT Perpustakaan } \\
\text { yang strategis }\end{array}$ & 2 & $\begin{array}{l}\text { Sumber daya manusia(Image } \\
\text { perpustakaan/ pustakawan) } \\
\text { Manajemen sistem informasi } \\
\text { perpustakaan (UNSLA) } \\
\text { Keterbatasan sumber } \\
\text { informasi/koleksi tercetak } \\
\text { Bargaining position yang } \\
\text { belum optimal }\end{array}$ \\
\hline & \multicolumn{5}{|l|}{ Faktor Eksternal } \\
\hline & Opportunities (O) & & Strategi SO & & Strategi WO \\
\hline 1 & $\begin{array}{l}\text { Market share yang } \\
\text { sudah tersegmetasi }\end{array}$ & 1 & $\begin{array}{l}\text { Membangun diferensiasi } \\
\text { layanan baru "Javanese } \\
\text { Corner" } \\
\text { dengan digitalisasi koleksi } \\
\text { Jawa Kuno (e-javanese } \\
\text { collections) }\end{array}$ & 1 & $\begin{array}{l}\text { Mengakomodasi kebutuhan } \\
\text { informasi berdasar } \\
\text { market share yang sudah } \\
\text { tersegmentasi } \\
\text { melalui liaison librarian }\end{array}$ \\
\hline \multirow[t]{3}{*}{2} & $\begin{array}{lr}\text { Jaringan } & \text { kerjasama } \\
\text { Forum } & \text { Kerjasama } \\
\text { P e r p u s t a k a a } n \\
\text { Perguruan } & \text { Tinggi } \\
\text { Negeri (FKP2TN) }\end{array}$ & 2 & $\begin{array}{l}\text { Menambah ragam konten } \\
\text { digilib (penelitian dosen) }\end{array}$ & 2 & 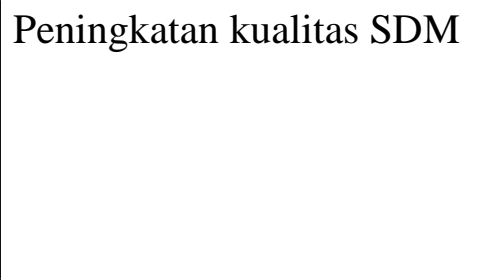 \\
\hline & & & & 3 & $\begin{array}{l}\text { Share collection melalui } \\
\text { kartu sakti FKP2TN dalam } \\
\text { memenuhi } \\
\text { koleksi yang tidak tersedia } \\
\text { di UNS }\end{array}$ \\
\hline & Threats (T) & & Strategi ST & & Strategi WT \\
\hline 1 & \begin{tabular}{|lc} 
Lambatnya & akselerasi \\
dalam & melakukan \\
inovasi & layanan \\
berbasis teknologi
\end{tabular} & 1 & $\begin{array}{l}\text { Layanan SAT sebagai media } \\
\text { penelusuran informasi } \\
\text { digital } \\
\text { Lokasi perpustakaan yang } \\
\text { strategis sebagai learning } \\
\text { space. Pustakawan berperan } \\
\text { dalam menciptakan / } \\
\text { membangun suasana } \\
\text { akademik di lingkungan } \\
\text { kampus }\end{array}$ & 1 & $\begin{array}{l}\text { Workshop literasi informasi } \\
\text { untuk semua pustakawan } \\
\text { UNS } \\
\text { Memunculkan pustakawan } \\
\text { profesional melalui "action" } \\
\text { nya kolaborasi dengan } \\
\text { tenaga pendidik (dosen) } \\
\text { untuk pemanfaatan teknologi } \\
\text { perpustakaan dalam } \\
\text { mendukung pendidikan dan } \\
\text { riset. }\end{array}$ \\
\hline
\end{tabular}

(Sumber: data primer diolah, 2015) 
Dengan melihat kondisi SWOT tersebut di atas, dapat diambil suatu strategi sebagai berikut.

\section{Strategi SO}

a. Javanese Corner

UPT Perpustakaan perlu membangun differensiasi layanan "Javanese Corner". Hal ini sebagai salah satu langkah dalam membangun positioning perpustakaan. Menurut Ries (dalam Kotler \& Keller 2013: 298), "Positioning is the act of designing a company's offering and image to occupay a distinctive place in the minds of the target market". Strategi menciptakan mindset di benak pengguna perpustakaan adalah penting, yaitu dengan menawarkan produk yang memiliki nilai lebih atau berbeda atau unik. Sangat tepat apabila UNS sebagai sebuah perguruan tinggi negeri di Solo bekerja sama dengan keraton dan museum untuk pengembangan koleksi Jawa. Hal ini sangat mendukung Solo sebagai kota budaya (budaya Jawa). Rujukan tentang koleksi jawa (kuno atau modern) bisa diakses di perpustakaan UNS. Untuk membangun Javanese Corner secara internal, bisa dilakukan dengan menyediakan ruangan khusus untuk koleksi Jawa. Saat ini, UPT Perpustakaan memiliki koleksi Jawa lebih dari 1000 judul, namun penataannya masih menjadi satu dengan buku umum. Akan lebih baik apabila koleksi Jawa, terutama koleksi kuno terbitan sebelum tahun 1930, dialihmediakan menjadi koleksi digital, kemudian dilayankan dalam bentuk e-book. Adapun kerja sama untuk membangun koleksi Jawa bisa dilakukan dengan javanologi institute UNS, ISI Solo, Perpustakaan Keraton Solo, Museum Solo, dan Leiden University.

Adapun tujuan membangun Javanese Corner, antara lain sebagai berikut.

1) Menciptakan positioning perpustakaan. Menjadikan UPT Perpustakaan UNS sebagai rujukan koleksi Jawa dengan membangun diferensiasi layanan, yaitu Javanese Corner. Diferensiasi produk adalah kegiatan yang dilakukan seorang pustakawan (dan/atau dengan tim IT) untuk menciptakan sebuah perbedaan yang bertujuan memberikan nilai lebih (competitive advantage) kepada pengguna. Diferensiasi bisa dilakukan dengan menciptakan produk yang berbeda, memberikan pelayanan yang berbeda, atau menciptakan image produk yang unik dan berbeda dari pesaing lainnya. Dengan begitu, sebuah produk akan lebih mudah dikenali dan memberikan daya tarik tersendiri bagi pengguna perpustakaan. Tujuan dari strategi diferensiasi adalah mengembangkan positioning yang tepat sesuai keinginan pengguna potensial yang ingin dituju. Siapa pengguna potensial UPT Perpustakaan UNS? Yaitu mahasiswa sastra daerah (Fakultas Ilmu budaya dan FKIP), para peneliti yang ada di Indonesia, maupun luar negeri.

2) Membangun mind identity UNS

UNS lahir dari kekuatan budaya lokal Jawa didukung dengan bangunan UPT Perpustakaan yang bernuansa arsitektur tradisional jawa (arah bangunan, atap limasan, ragam hias). Keberhasilan suatu layanan perpustakaan akan bermuara pada cara pandang pengguna terhadap perpustakaan dan pustakawan. Harapannya, image pustakawan menjadi lebih baik melalui penciptaan brand perpustakaan.

b. Menambah ragam konten digilib (penelitian dosen)

Digital library UNS adalah sebuah repository yang berisi karya ilmiah civitas akademika. Beragamnya jenis koleksi dan disiplin ilmu yang dikaji akan memberikan beragam pengetahuan bagi pencari informasi. Kelengkapan koleksi akan berpengaruh terhadap tingginya akses ke perpustakaan. 


\section{Strategi WO}

a. Market share yang sudah tersegmentasi

UNS memiliki market share yang sudah tersegmentasi, yaitu sepuluh fakultas dan program pascasarjana. Maka, perlu pemenuhan kebutuhan informasi melalui kebijakan pusat. Untuk pemenuhan kesesuaian kebutuhan koleksi, peran dosen sebagai pengajar di tiap mata kuliah wajib untuk mengajukan usulan buku yang digunakan dalam proses pembelajaran (referensi wajib dan referensi pendukung). Menurut SNI Perpustakan Perguruan Tinggi oleh BSN, penambahan koleksi sekurang-kurangnya $2 \%$ dari jumlah judul atau minimal dua ratus judul per tahun dipilih mana yang paling besar. Dengan demikian, akan meminimalisasi anggapan bahwa perpustakaan bukunya usang, lama, dan tidak up to date. Untuk mempermudah pengadaan koleksi based on user, perlu dibentuk liaison librarian. Kesesuaian koleksi perpustakaan dengan kebutuhan pengguna merupakan salah satu indikator kualitas perpustakaan. UNS yang terdiri dari beragam prodi dan tingkat pendidikan tentu saja membutuhkan koleksi dengan beragam disiplin ilmu.

Untuk mempermudah dalam pengadaan/pengembangan koleksi, perlu dibentuk liaison librarian sebagai seorang mediator (connectors) yang mengubungkan fakultas di lingkungan perguruan tinggi dengan UPT Perpustakaan. Kebutuhan fakultas dalam mendukung proses pembelajaran bisa dikomunikasikan pada masing-masing liaison librarian. Misalnya, tentang usulan pengadaan koleksi, permintaan sosialisasi perpustakaan, pelatihan literasi informasi, peminjaman library room untuk diskusi, dan sebagainya. Dengan demikian, ada action pustakawan dan akan merubah image menjadi lebih baik. Penguasaan aplikasi teknologi, kemampuan berkomunikasi, serta pengetahuan tentang sumber-sumber informasi adalah kompetensi utama liaison librarian.

b. Peningkatan Kualitas SDM

SDM memegang peranan penting dalam membangun perpustakaan. Adapun kemampuan yang dibutuhkan adalah technology skills dan interpersonal skills. Setidaknya UPT perpustakaan UNS membutuhkan SDM di bidang IT. Great Library Great Technology. Di era informasi, teknologi menjadi kunci keberhasilan perpustakaan dalam menjalankan fungsinya sebagai pengelola dan share informasi (pengetahuan). UPT Perpustakaan adalah sebuah organisasi yang besar dan sebagai jantung PT, maka sudah selayaknya memiliki tenaga IT dalam hal ini programmer sehingga permasalahan-permasalahan yang muncul dalam bidang IT (sistem informasi perpustakaan) dapat tertangani dengan cepat. Pengembangan SDM bisa diawali dengan memanfaatkan Forum Kerjasama Perpustakaan Perguruan Tinggi Negeri (FKP2TN) sebagai jejaring kerja sama perpustakaan di tingkat nasional.

c. Share collection melalui kartu sakti FKP2TN

Dalam memenuhi kebutuhan koleksi yang tidak tersedia di perpustakaan UNS, bisadiatasidengan share collection melalui kartu sakti FKP2TN (Forum Kerjasama Perpustakaan Perguruan Tinggi Negeri). Kerja sama antarperpustakaan PTN di Indonesia dalam resource sharing melalui kartu sakti, yang dapat digunakan di seluruh perpustakaan anggota FKP2TN. Pemegang kartu tersebut dapat mengakses dan memanfaatkan koleksi yang dimiliki oleh perpustakaan yang dituju. 
3. Strategi ST

a. Pemanfaatan Self Access Terminal (SAT) sebagai media penelusuran informasi digital melalui peran pustakawan.

SAT (penelusuran internet) memungkinkan untuk dimaksimalkan khusus penelusuran informasi terhadap akses e-resources dalam bidang pendidikan. Dalam hal ini, pustakawan memberikan layanan bimbingan pemakai dan penelusuran informasi. Tentu saja hal ini membutuhkan pustakawan yang memilki kompetensi dalam menelusuri informasi, bahasa Inggris, dan menjadi seorang subjek specialist.

b. Lokasi perpustakaan yang strategis sebagai learning space

Perpustakaan perguruan tinggi sebagai unsur penunjang proses pendidikan, penelitian, dan pengabdian masyarakat mempunyai peran penting dalam keberhasilan studi mahasiswa. Freeman (2005: 1) menyatakan:

"The academic library has always held a central position as the heart of an institution-both symbolically and in terms of its physical placement. Preeminently sited and often heroic in scale and character, the library has served as a visual anchor for the surrounding buildings on campus".

Secara signifikan, perpustakaan harus berfungsi sebagai bangunan utama di kampus dan tempat bertemunya kalangan akademik dari berbagai expert sehingga atmosphere academic akan terbangun dan menjadi budaya kampus.

4. Strategi WT

a. Workshop literasi informasi untuk semua pustakawan UNS

Pustakawan sebagai pengelola informasi sudah seharusnya tahu di mana mencari informasi, bagaimana cara mencari informasi yang tepat, dan bagaimana cara menggunakan informasi tersebut secara benar. Hal ini sudah menjadi tuntutan profesi, apalagi di era informasi telah memunculkan generasi digital native. Kemampuan literasi informasi yang dimiliki oleh pustakawan sebagai langkah awal dalam menuntun pencari informasi untuk dapat menemukan informasi secara cepat, tepat, dan benar, yang bermuara pada terbentuknya self-directed learning. Di era teknologi, akselerasi teknologi di perpustakaan adalah agenda utama di era pengguna digital native.

Dalam hal ini, pustakawan seharusnya memiliki keahlian dalam mengorganisasi informasi, metadata, akses ke sumber informasi, penyebaran pengetahuan, strategi penelusuran informasi, pengetahuan menilai keakurasian atau kebenaran sumber informasi ilmiah, dan memfasilitasi koneksi pengguna (civitas akademika) di bidang ilmiah. Namun demikian, belum semua pustakawan memiliki kompetensi tersebut. Hal inilah yang menjadikan lambatnya akselerasi dalam melakukan layanan berbasis teknologi. Perlu ada agenda mengikutsertakan pustakawan dalam pendidikan dan pelatihan kepustakawanan yang diselenggarakan oleh pemerintah (http://pusdiklat.perpusnas.go.id) ataupun yang diselenggarakan swasta.

b. Memunculkan pustakawan profesional (di antara beberapa pustakawan UNS)

Hal tersebut dapat dilakukan melalui action pustakawan dengan berkolaborasi dengan tenaga pendidik (dosen) untuk pemanfaatan teknologi perpustakaan dalam mendukung pendidikan dan riset. Misalnya, melalui akses e-resources, pemanfaatan scopus, plagiarism 
checker technology, pemanfaatan mendeley, submit international journal, memfasilitasi koneksi di bidang ilmiah, dan sebagainya.

\section{PENUTUP}

Membangun eksistensi sebuah lembaga di era kompetisi memerlukan strategi yang tepat. Melalui analisis SWOT tentang UPT Perpustakaan UNS, dihasilkan beberapa strategi untuk pengembangan perpustakaan ke depan. Saatnya keluar dari "zona nyaman" untuk menuju perubahan dan membangun eksistensi perpustakaan melalui implementasi formulasi strategi sebagai berikut. Pertama, strategi SO adalah formulasi yang diambil dengan menggunakan kekuatan dan kesempatan internal UPT Perpustakaan UNS, meliputi: 1) UPT Perpustakaan perlu membangun differensiasi layanan "Javanese Corner"; 2) menambah ragam konten digilib (penelitian dosen). Kedua, strategi WO adalah formulasi yang diambil dengan menggunakan kesempatan yang ada untuk meminimalisasi atau mereduksi kelemahan UPT Perpustakaan UNS, meliputi: 1) UNS memiliki market share yang sudah tersegmentasi (sepuluh fakultas dan program pascasarjana), maka perlu pemenuhan kebutuhan informasi melalui kebijakan pusat; 2) pengajuan programer untuk pengembangan SIM Perpustakaan; 3) share collection melalui kartu sakti FKP2TN dalam memenuhi kebutuhan koleksi yang tidak tersedia di perpustakaan UNS.

Ketiga, strategi ST adalah formulasi dengan menggunakan kekuatan yang ada untuk menghambat atau mengurangi ancaman yang ada, meliputi: 1) pemanfaatan SAT (Self Acces Terminal) sebagai media penelusuran informasi digital melalui peran pustakawan; 2) lokasi perpustakaan yang strategis sebagai learning space. Keempat, strategi WT adalah formulasi dengan mencari kemungkinan pemanfaatan kelemahan dan ancaman yang ada di UPT Perpustakaan UNS, meliputi: 1) workshop literasi informasi untuk semua pustakawan UNS; 2) memunculkan/memberdayakan pustakawan profesional (di antara beberapa pustakawan UNS) melalui action-nya berkolaborasi dengan tenaga pendidik (dosen) untuk pemanfaatan teknologi perpustakaan dalam mendukung pendidikan dan riset

Pengakuan bahwa perpustakaan dibutuhkan, dicari, dan digunakan dapat dilihat melalui "action" pustakawan sehingga perpustakaan sebagai jantung perguruan tinggi tidak hanya sebatas ungkapan, tetapi sebuah proses yang dibangun melalui tindakan nyata pustakawan sebagai pengelola informasi. Sebagai sebuah organisasi yang terstruktur, diperlukan kolaborasi dengan stakeholder dan pengambil keputusan di tingkat universitas untuk mewujudkan tata kelola yang berkesinambungan dalam mewujudkan visi universitas.

\section{DAFTAR PUSTAKA}

Badan Standardisasi Nasional. tt. Standar Nasional Indonesia: SNI 7330:2009. Jakarta: Badan Standardisasi Nasional.

Freeman, Geoffrey T.. 2005. "The Library as Place: Changes in Learning Patterns, Collections, Technology, and Use". In Library as Place: Rethinking Roles, Rethinking Space. Washington, DC: Council on Library and Information Resources.

Gymnastiar, Abdullah \& Kartajaya, Hermawan. 2004. Berbisnis dengan Hati: The 10 Credos of Compassionate Marketing. Jakarta: MarkPlus\&Co. 
Kotler, Philip \& Keller, Kevin Lane. 2013. Marketing Management. Boston: Pearson.

Mapulanga, Patrick. 2013. "SWOT Analysis in The Planning of Information Services and Systems in University Libraries". The Bottom Line, 26(2), pp. 70 - 84. Accesed Okt 7, 2015, permanent link to this document: http://dx.doi.org/10.1108/BL-12-2012-0034.

Rothaermel, Frank T.. 2013. Strategic Management: Concepts \& Cases. New York: Mc.Graw-Hill.

Team MFE.. 2013. “SWOT Analysis Strategy Skill”. Accesed Okt 8, 2015, from www.free managementebooks.com.

Wikipedia. tt. Strategic Management. Accesed July 10, 2015 from https://en.wikipedia.org/ wiki/ Strategic_management. 